Kudinov, I. S. et al. (2020). Different self-attitude indicators in students and their self-realization in a University, International Journal of Cognitive Research in Science, Engineering and Education (IJCRSEE), 8(3), 47-59.

Original scientific paper

UDK:

Received: September, 10.2020.

Revised: October, 20.2020.

Accepted: October, 30.2020.

159.923.2.075-057.475(470)"2019/2020"

doi: 10.23947/2334-8496-2020-8-3-47-59

\title{
Different Self-Attitude Indicators in Students and Their Self-Realization in
}

\section{a University}

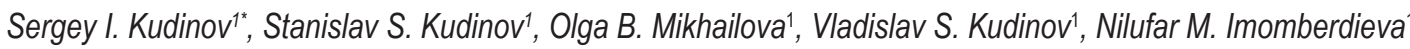

${ }^{1}$ Chair of Social and Differential Psychology, Peoples' Friendship University of Russia (RUDN University), Moscow, Russia, e-mail: kudinov_si@pfur.ru; kudinov_ss@pfur.ru; olga00241@yandex.ru; 1032173555@rudn.ru; 1042180202@rudn.ru

\begin{abstract}
The problem raised in the study is also due to the lack of a common conceptual framework explaining the conditionality of foreign students' realization by subjective characteristics. The purpose of the paper is to present and analyze the results of an empirical study of self-attitude indicators as subject predictors of students' self-realization in a foreign cultural environment. The study was conducted in 2019-20 among students of the Peoples' Friendship University of Russia getting undergraduate and Master's degrees in Humanities. 412 respondents aged 18-25 took part in the survey. The authors used "Multidimensional questionnaire of self-identity" method by S. I. Kudinov; "Test - questionnaire of self-attitude" method by V. V. Stolin, S. R. Panteleev; the self-assessment diagnostic technique by Dembo-Rubinstein in A. M. Prikhozhan's modification; "Individual preferences of self-expression sphere" questionnaire by S. S. Kudinov; methods of mathematical and statistical analysis (descriptive statistics, cluster analysis, K. Pearson's correlation analysis, factor analysis, the program of standard statistical package "Statistica-7.0". In the course of an empirical study of students in a multinational university it was found that the respondents' self-realization is carried out mainly in the course of educational activities. As a result of cluster analysis, three groups of respondents with dominant indicators of self-attitude have been identified, which were conventionally designated as positive-stable, negative-rigid and socially dependent type of self-attitude. It is determined that respondents with a positivestable type of self-attitude demonstrate most successful self-fulfillment due to the expression of such personal qualities as selfacceptance, self-confidence, faith in their possibilities and abilities, self-management. At the same time, the greatest difficulties in self-realization are experienced by students with a socially dependent type of self-attitude, due to low self-esteem, external self-regulation and constant expectation that others would evaluate their activities, actions and reactions.
\end{abstract}

Keywords: students, self-realization, self-attitude, clusters, variables, characteristics, respondents.

\section{Introduction}

The relevance of the research presented in this paper is determined by the escalation of modern national-ethnic tension between individual national-ethnic clusters, as well as by the socio-economic crisis both in Russia and in Europe. An increasing number of people, especially at a young age, find themselves in difficult situations, mainly in countries with low economic potential. As a result, young people in the context of professional self-determination seek higher professional education in other countries, including Russia. Previous research shows that not all students are able to complete their studies successfully. The difficulties of mastering the educational program are explained by such factors as socio-psychological adaptation and acculturation of young people, difficulties and obstacles to their self-realization in the context of educational activities, peculiarities of self-attitude caused by past negative life experience and foreign cultural socio-educational environment (Hartung, Porfeli and Vondracek, 2005; Galazhinskij, 2006; Stošić, L. et al., 2020).

Modern pedagogical systems of Russian education set the task of spiritual and moral development of the individual as the main one, along with the formation of professional competencies. Self-attitude, self-determination, self-regulation, self-education, self-development and self-realization are of particular relevance here.

This philosophical paradigm makes modern education focus on the maximum disclosure of a person's creative independence, personal potential, initiative, and individual identity. Increased requirements are placed on professional and personal competence, personal activity, and the student's self-realization.

This problem is most acute for internationally oriented universities, where students from different

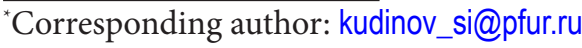


countries study in a multicultural educational space. The combination of needs, internal necessity and external unfavorable conditions of self-realization is a particularly important problem for international students. This issue becomes the most attractive in modern conditions, when foreign students face the challenges of resisting the negative factors of the multicultural environment, on the one hand, and preserving their own plan of self-realization, on the other. In this context, it is important to reveal the psychological characteristics that mediate the achievement of the individual's successful self-realization. Since many authoritative researchers call self-realization a criterion of mental health and the success of a person's life path (Bandura, 1995; Stošić and Stošić, 2015; Stošić and Fadiya, 2017; Leontiev, et al., 2017).

The problem of self-realization research is that a huge number of theoretical approaches to understanding this phenomenon do not give an answer to the question of self-realization genesis, its essential characteristics, structural mechanisms, conditions and factors of manifestation. The methodological difficulty of studying this psychological education is the lack of reliable and valid psychodiagnostic tools. If we look at the domestic and foreign experience of studying self-realization, we can see that the research of this phenomenon is dominated by linear analytical strategies with a thorough analysis of a single variable of self-realization. Representatives of psychoanalysis were concentrating on the needs. Proponents of the humanistic approach analyzed mainly motives, needs, and meanings. Behaviorists considered the behavioral side of self-realization (Kudinov and Kudinov, 2017). Russian researchers have repeatedly attempted a systematic study of self-realization, but a completely convincing and thorough system concept has not been developed.

The approach outlined in the works of L. A. Korostyleva deserves the most attention. In particular, L. A. Korostyleva defines the self-realization of the individual as the implementation of opportunities for the development of the Self through their own efforts, activities, co-creation with other people, society and the world as a whole. Self-realization presupposes a balanced and harmonious development of various aspects of the personality through the application of adequate efforts aimed at the disclosure of genetic, personal and individual potentials (Korostyleva, 1997).

Currently, the works in which different personality and individuality features act as indicators of personal self-realization have become widely popular (Berzonsky and Papini, 2014; Kudinova and Belousuva, 2017; Kudinov et al., 2019; Solodnikova, 2018). In some studies, gender and social stereotypes are considered to be predictors of self-realization (Chzhan and Chzhan 2013; Denisova and Vorobyeva, 2017). It can also be noted that in some studies, the system-forming determination of subject's selfrealization is creative potential (Kulagina, 2016). In addition, the scientists emphasize the positive role of adaptability and resilience in the success of self-realization in different life situations (Hammad, 2013; Kostakova and Belousova, 2014); specifics of self-realization during professional training (Leary et al., 1994; Waterman et al., 2003; Kudinov and Aybazova, 2015; Kudinov and Kudinov, 2017); self-realization features in different types of professional activity (Kudinov et al., 2012; Kudinov et al., 2018; Egorycheva, 2019); self-realization in the third age (Solodnikova, 2018). Studies of self-realization in sick people and people with disabilities are conducted separately (Bokhan and Peshkovskaya, 2011; Chzhan, 2013).

This study examines the characteristics of students' self-realization in a multicultural educational environment of the University. In a broad sense, a multicultural environment is a part of the social environment that surrounds a person, positively or negatively affecting his/her development, and is a combination of all living conditions, taking into account the ethnic characteristics of the place of residence, expressed in people, their behavior, folk traditions, and rituals. A multicultural educational environment is a part of the educational environment that represents a set of conditions that affect the formation of an individual, its readiness for effective interethnic and intercultural interaction, empathy, understanding of other cultures and ethnic cultures, and tolerance towards representatives of other cultures and ethnic groups (Yudakina, 2013).

We believe that such characteristics can be self-attitude, self-esteem and self-perception of the individual, which demonstrate the ability of the individual to resist difficult socio-cultural situations and realize the needs and aspirations for self-realization.

\section{Materials and Methods}

The purpose of the study is to identify and analyze the characteristic features of self-attitude indicators as subject predictors of students' self-realization in the foreign-cultural educational environment of the University. In connection with this goal, the research area is aimed at identifying the features of self-realization in students with different characteristics of self-attitude. 
Self-relation is considered as a psychological phenomenon of personality, manifested in the characteristics of self-realization of the individual. This is a stable personal property, which is expressed in the unity of ideas and experiences of a person regarding their own value and determines their meaninglife orientations. Self-attitude can manifest itself in an emotional attitude to the Self and consist of such components as: self-respect, self-acceptance, self-love, self-esteem, self-confidence, self-deprecation, self-blame (Vartanova, 2016). As a structure of personality, self-relation is formed primarily in interpersonal interaction under the influence of many external and internal psychological factors.

The theoretical and methodological basis for the study of the subjective determination of students' self-realization in the multicultural educational space is an existential approach, in the context of which the uniqueness of the individual acts as a specific trajectory of the subject's self-realization (Guichard, 2005; Vianello et al., 2013); a subject-activity approach that explains the identification of the individual internal potential in direct educational and professional activities; theories and concepts of personality that consider the prerequisites for the personal behavior manifestation in social situations, taking into account external and internal factors (Grigorieva and Povarionkov, 2015; Leontiev, et al., 2017); modern approaches to higher education that regulate the self-developing educational space which activates selfdisclosure, self-actualization and self-realization of the subject of activity.

The modern university is a part of the multicultural educational environment of society and implements a certain system of conditions and influences through education on the individual in order to form an attitude to oneself, to other people and to multicultural relations. University education in general not only forms professional skills, but also develops the ability to effectively interethnic and intercultural interaction and self-realization of the individual in a modern multi-ethnic society.

The basis of this research was the polysystem concept of self-realization of the individual developed and justified by S. I. Kudinov. The main postulates in the construction of a polysitemic concept of selfrealization of the individual, from our point of view, can serve as the following grounds: 1) a complex of multi-level systems that ensure the success of self-realization of the individual; 2) research of selfrealization as a functional system that reveals the connections and relationships between its various levels of the system and characteristics; the opportunity to study both horizontal and vertical linkages between different systems and characteristics of self-realization; 3 ) the rationale of strategic, integrative formations of self-realization; 4) focus on the study of individual characteristics of personal self-realization (Kudinov, 2013; Kudinov et al., 2015). The psychological conditions that contribute to the degree of success of self-realization are mental and cognitive processes, personality traits and emotional state (Kudinov et al, 2012).

We also consider the polysystem concept of personal self-realization that reveals the subjective mechanism of self-expression of the individual's abilities and capabilities, taking into account external conditions and factors (Kudinov et al., 2015).

Methods of research:

- to identify the specifics of self-evaluation of respondents, the authors used the technique of "Test-questionnaire of self-attitude" by V. V. Stolin, S. R. Panteleev (Kudinov and Kudinov, 2018); the technique of self-evaluation diagnostics by Dembo-Rubinstein modified by A. M. Prikhozhan (Kudinov and Kudinov, 2018); to study the students' self-realization in a multicultural learning environment they applied S. I. Kudinov's method "Multidimensional questionnaire of self-identity" (Kudinov and Kudinov, 2017); a method - questionnaire "Individual preferences of self-expression sphere" by S. S. Kudinov (Kudinov et al., 2015); expert evaluation.

- mathematical and statistical analysis included methods of descriptive statistics; cluster analysis, K. Pearson's correlation analysis, factor analysis; statistical data processing was carried out using the program "SPSS 19.0 for Windows".

To identify individual and typological features of self-attitude in respondents, a cluster analysis was used, which allowed to determine the specifics of self-perception, self-esteem and self-attitude in subjects of the educational space. Correlation analysis was used to establish stable links between individual variables of self-relation and self-realization, indicating the interdependence of these characteristics. Using factor analysis, the structure of self-realization in subjects with different types of self-attitude was revealed.

The study, which was conducted in 2019-20, involved 412 students of the Humanities departments of the Peoples' Friendship University of Russia, studying undergraduate and Master's degrees at the age of 18-25 years, of which 229 are female and 183 are male. These respondents come from different countries of the world and are representatives of different national cultures. When conducting and analyzing the empirical results, all ethical aspects of the organization of modern research were taken into account. The Ethical Committee of the Department of Social and Differential Psychology of the Peoples' 
Friendship University of Russia, led by the head of the Department, Professor S. I. Kudinov, approved and supported the research program.

\section{Results}

In the course of conducting an empirical study, the data obtained by the ratio for the entire sample were subjected to cluster analysis. In the course of the cluster analysis, three clusters were identified with a fairly contrasting division of the self-relationship components. When clustering using the "K-medium" method, it was found that clusters differ significantly on most scales, with the exception of self-esteem and self-acceptance between the second and third clusters, where no statistically significant differences were found. The selected clusters characterize the characteristics of the respondents' self-attitude from full self-acceptance to negative perception of their own self. Let's look at the selected clusters in more detail (Figure 1).

\begin{tabular}{|c|c|c|c|c|c|c|c|c|c|c|}
\hline $\begin{array}{r}1 \\
0,5\end{array}$ & & & & & & 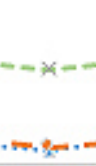 & & & &. \\
\hline$-0,5$ & & & & & & & & & & \\
\hline-1 & $\begin{array}{l}\text { Self- } \\
\text { asses } \\
\text { sment }\end{array}$ & $\begin{array}{c}\text { Closed } \\
\text { ness }\end{array}$ & $\begin{array}{c}\text { Negative } \\
\text { self- } \\
\text { attitude }\end{array}$ & $\begin{array}{l}\text { Confi } \\
\text { dence }\end{array}$ & $\begin{array}{c}\text { Self- } \\
\text { manage } \\
\text { ment }\end{array}$ & $\begin{array}{l}\text { Self- } \\
\text { evalu } \\
\text { ation }\end{array}$ & $\begin{array}{c}\text { Self- } \\
\text { accep } \\
\text { tance } \\
\end{array}$ & $\begin{array}{l}\text { Self- } \\
\text { attach } \\
\text { ment }\end{array}$ & $\begin{array}{c}\text { Internal } \\
\text { conflict }\end{array}$ & $\begin{array}{l}\text { Self- } \\
\text { blame }\end{array}$ \\
\hline$\ldots \ldots, \ldots$ Cluster 3 & 0,18 & 0,84 & 0,23 & 0,23 & 0,17 & 0,09 & 0,19 & 0,22 & 0,25 & 0,69 \\
\hline$-\approx-$ Cluster 2 & 0,21 & 0,29 & 0,29 & 0,17 & 0,22 & 0,11 & 0,18 & 0,68 & 0,87 & 0,92 \\
\hline$--x--$ Cluster 1 & 0,88 & 0,13 & 0,75 & 0,81 & 0,72 & 0,64 & 0,73 & 0,19 & 0,07 & 0,12 \\
\hline
\end{tabular}

Figure 1. Indicators of self-attitude in clusters

The first cluster is represented by 97 students. These respondents demonstrated the most pronounced indicators of self-attitude on most scales. Their distinctive features are high self-esteem $(n=0.88)$, reflected self-attitude $(n=0.75)$, self-confidence $(n=0.81)$, self-management $(n=0.72)$, self-worth $(n=0.64)$ and self-acceptance $(n=0.73)$. At the same time, in this group there is a weak degree of closed nature $(n=0.13)$, internal conflict $(n=0.07)$ and self-blame $(n=0.12)$.

These students demonstrate reflection and self-understanding, they are critical of their own qualities and merits, and they focus solely on their own vision and assessment of the situation in communication and interaction with others. They have marked self-confidence, dominant motivation for achievement and success in activities and behavior, high courage in communication and interaction. They positively evaluate all their undertakings and achievements, feel their abilities and opportunities to solve difficult life situations. Difficulties and obstacles do not stop them, they are not prone to long-term reflection if something does not work out. They highly appreciate their internal potential, their capabilities, the uniqueness of their own resources, and their originality. Self-confidence helps these respondents resist environmental influences and rationally accept criticism. They tend to accept themselves as they are with all the advantages and disadvantages. Their shortcomings are considered a continuation of their advantages. They consider themselves exceptionally good and successful people. They have a pronounced positive psycho-emotional mood in their activities, communication and behavior. This type of respondents' self-evaluation can be conventionally termed as positive-stable, since, on the one hand, they openly show positive emotional attitude to their own personality and, on the other, and a thoughtout and balanced rational approach to presenting their potential, to demonstrating their capabilities in communication, activities and behavior is shown.

Respondents included in the second cluster of 171 people have a high level of self-blame $(n=0.92)$, internal conflict $(n=0.87)$, and self-attachment $(n=0.68)$. At the same time, they revealed an understated level of self-esteem ( $n=0.21)$. The weak components of self-attitude are self-worth $(n=0.11)$, self-confidence $(n=0.17)$, self-acceptance $(n=0.18)$, and self-management $(n=0.22)$. The severity of these imbalances in self-attitude characteristics indicates that these respondents are characterized by self-blame in deeds and actions; they are ready to take the blame for all their failures. Their attitudes and protective mechanisms 
are focused on self-blame, which leads to the formation of internal tension, discomfort and inability to meet current needs. They are dominated by a negative attitude towards themselves, which leads to increased control of their inner world. Their expressed reflection manifests itself in a negative assessment of their personal qualities, while the high self-demand generates a conflict between the real "self" and the ideal "self", between the level of claims and real achievements. Another pronounced feature is their rigidity of the "self" concept, the desire to preserve all their qualities unchanged, which in turn hinders the possibility of their development and self-improvement. Low self-esteem and self-flagellation lead to the development of anxiety, which is also a hindrance to self-expression. The combination of these characteristics allows us to call this type of self-attitude - negative-rigid. The peculiarities of the attitude to oneself, one's inner world and one's potential opportunities express a predominantly negative emotional character, which is an obstacle to full and open self-expression.

The third cluster included 154 students whose self-relation variables' expression hierarchy is dominated by closeness $(n=0.84)$ and self-blame $(n=0.69)$. At the same time, they are reported to have low self-esteem and a critically low level of self-worth. This set of characteristics indicates the protective behavior of these respondents, internal closeness and a desire to conform to generally accepted norms in society. They tend to consciously ignore open relationships with themselves; the reason for this may be a reluctance to reveal themselves and the refusal to recognize the presence of personal problems. Compliance with generally accepted social norms gives the respondents a reason to perceive themselves as accepted in the society. At the same time, they see themselves as mostly flawed and are willing to take the blame for all the failures and blunders. They underestimate their uniqueness due to low selfesteem; in this regard, they experience self-doubt, which reduces their resistance to external negative factors. Increased sensitivity to comments and criticism of others in their address makes them touchy and vulnerable, prone to distrust their individuality. The analysis of the presented characteristics gives grounds to name this cluster as a socially dependent type of self-attitude.

It should be noted that the results of cluster analysis allowed us to establish a number of distinctive features in the manifestations of self-attitude among students.

The specificity of students' self-realization considering different indicators of self-attitude was analyzed by factor analysis. The results of the study showed that self-expression of foreign students in a multicultural educational environment most often occurs in educational and research activities (Table 1).

Table 1

Distribution of the main areas of students' self-realization in \% $(n=412)$

\begin{tabular}{ccccc}
\hline Studying & $\begin{array}{r}\text { Research } \\
\text { activities }\end{array}$ & Sport & Creativity & Social work \\
\hline $57 \%$ & $14 \%$ & $7 \%$ & $13 \%$ & $9 \%$
\end{tabular}

According to the empirical study, foreign students fulfil their potential in the field of educational activities, which is quite expected, since educational activities are associated with their professional development. Research and creative spheres of self-realization occupy the second and third positions. Some students are already involved in research projects from the first year of study at the university and usually continue their studies at the postgraduate level. Creative students, along with their academic activities, express themselves in music, theater, and other projects of the university. Nine percent of students are willingly engaged in social activities. They are members of all kinds of social communities, are the headmen in groups, are included in student social projects. A small percentage of foreign students realize themselves in sports.

The analysis of various spheres of self-realization of students with the identified types of self-attitude showed that respondents with a positive and stable self-attitude are distributed among all the presented areas. At the same time, the main ones are educational, research and social spheres. Students with a negative-rigid type of self-attitude express themselves mainly in the educational and creative spheres of activity, while respondents with a socially dependent type are more self-actualized in the educational process.

At the next stage of the study, a factor analysis of self-realization components was performed to confirm the hypothesis about the self-attitude influence on the success of self-expression in the multicultural educational space (Table 2). 
Kudinov, I. S. et al. (2020). Different self-attitude indicators in students and their self-realization in a University, International Journal of Cognitive Research in Science, Engineering and Education (IJCRSEE), 8(3), 47-59.

\section{Table 2} $(n=97)$

Factor structure of self-realization variables in students with a positive-stable type of self-attitude

\begin{tabular}{lrrr}
\hline Variables of self-realization & Factor 1 & Factor 2 & Factor 3 \\
\hline Transformation ideas & 0,467 & $\mathbf{0 , 9 0 3}$ & $-0,127$ \\
\hline Adaptation ideas & $-0,135$ & 0,365 & $\mathbf{0 , 6 2 1}$ \\
\hline Activity & $\mathbf{0 , 8 5 6}$ & 0,208 & 0,174 \\
\hline Inertia & $-0,143$ & 0,206 & 0,291 \\
\hline Optimism & $\mathbf{0 , 8 2 9}$ & 0,013 & $-0,044$ \\
\hline Pessimism & $-0,281$ & $-0,059$ & $\mathbf{0 , 5 4 8}$ \\
\hline Internal locus of control & $\mathbf{0 , 7 8 7}$ & $-0,262$ & $-0,243$ \\
\hline External locus of control & $-0,311$ & 0,364 & $\mathbf{0 , 6 8 5}$ \\
\hline Motives for achievement & $\mathbf{0 , 7 4 9}$ & 0,264 & $-0,131$ \\
\hline Motives for avoidance & 0,162 & $\mathbf{0 , 6 2 1}$ & 0,124 \\
\hline Creativity & $\mathbf{0 , 7 7 4}$ & 0,354 & $-0,111$ \\
\hline Conservatism & 0,322 & 0,027 & $\mathbf{0 , 6 4 1}$ \\
\hline Satisfaction with quality of life & $\mathbf{0 , 6 9 2}$ & 0,221 & 0,058 \\
\hline Dissatisfaction with the quality of life & $-0,102$ & 0,267 & 0,173 \\
\hline Effectiveness & $\mathbf{0 , 5 6 9}$ & 0,201 & 0,072 \\
\hline Situational barriers & 0,092 & $\mathbf{0 , 5 7 3}$ & 0,063 \\
\hline Personal barriers & 0,034 & 0,132 & 0,146 \\
\hline
\end{tabular}

According to the data presented in the table, the first factor with significant values included such components as activity, optimism, internal locus of control, motivation for achievement, creativity, satisfaction with the quality of life and performance. These characteristics determine the specificity of these students' self-fulfillment to a greater extent than the others. Qualitatively, this is shown in the fact that respondents have a high index of social and cognitive activity, they strive to express themselves as often as possible in various spheres of life. They are dominated by a positive psycho-emotional mood, which allows them to look with confidence and hope for success in all endeavors. At the same time, they rely solely on their capabilities and abilities in their activities and behavior; they analyze possible failures and plan new programs to achieve results, considering their failures. Their expression is always creative in nature and focused exclusively on the success, on the result. Creativity manifests itself not only in ways of thinking and imagining, but also as a form of their self-realization. They have the ability to present themselves at their best. They resort to various ways and techniques of self-expression. Their life activities in the field of education, research, creativity and sports bring not only satisfaction, but also high performance.

The second factor with significant values included transformation ideas, avoidance motives, and situational barriers. This set of variables indicates that students, when expressing themselves, tend to change the surrounding reality in many ways, transform relationships, activities, organize relationships, etc. However, in difficult situations, where they lack experience, knowledge and social support, they tend to circumvent these situations, or choose a tactic of adaptation.

The third factor, which with significant values included attitudes to adaptation, pessimism, external self-regulation and conservatism indicate that in difficult situations, where cognitive or interethnic misunderstandings in a multicultural educational environment and other difficulties manifest themselves, students are more likely to adapt to the situation or circumstances, listen to others and at the same time refuse some of the responsibility for events. At the same time, their emotional mood decreases and as a result, they show less creative, non-standard ways and techniques of self-expression. In general, it should be noted that students with a positive-rational type of self-attitude have the highest index of success in self-realization, as evidenced by the level of expression of the above characteristics in the hierarchical and factor structure.

Table 3 shows similar results for students with an asthenic-unstable type of self-attitude. 
Table 3

Factor structure of the variables of self-realization among students with negative and rigid type of self-evaluation $(n=171)$

\begin{tabular}{lrrr}
\hline \multicolumn{1}{c}{ Variables of self-realization } & Factor 1 & Factor 2 & Factor 3 \\
& & & \\
\hline Transformation ideas & 0,015 & 0,156 & 0,211 \\
\hline Adaptation ideas & 0,105 & 0,187 & 0,673 \\
\hline Activity & 0,203 & 0,078 & 0,125 \\
\hline Inertia & 0,149 & $\mathbf{0 , 5 6 9}$ & 0,207 \\
\hline Optimism & 0,097 & 0,014 & $-0,124$ \\
\hline Pessimism & $\mathbf{0 , 7 1 4}$ & 0,152 & 0,138 \\
\hline Internal locus of control & 0,212 & $-0,143$ & $-0,115$ \\
\hline External locus of control & 0,223 & $\mathbf{0 , 6 6 9}$ & 0,171 \\
\hline Motives for achievement & 0,065 & 0,138 & $-0,097$ \\
\hline Motives for avoidance & 0,673 & 0,118 & 0,231 \\
\hline Creativity & 0,017 & 0,056 & 0,099 \\
\hline Conservatism & 0,124 & $\mathbf{0 , 7 2 1}$ & 0,227 \\
\hline Satisfaction with quality of life & 0,202 & 0,152 & $-0,605$ \\
\hline Dissatisfaction with the quality of life & 0,241 & $\mathbf{0 , 5 8 8}$ & 0,203 \\
\hline Effectiveness & 0,235 & 0,231 & 0,119 \\
\hline Situational barriers & $\mathbf{0 , 6 7 1}$ & 0,219 & 0,154 \\
\hline Personal barriers & 0,238 & 0,166 & 0,655 \\
\hline
\end{tabular}

As shown in the table, the factor structure of self-realization in students with a negative-rigid type of self-attitude differs slightly from the previous one. The first factor with significant values is represented by such components of self-realization as pessimism, motives of avoidance and situational barriers. These characteristics in the first factor are consistent with these respondents' self-attitude typology. Their contradictory, ambiguous and often underestimating attitude to their own person affects their selfexpression. They most often experience a negative mood, a decline in strength, a negative prediction of the results of their activities, etc. For this reason, they are guided in their activities and behavior by motives of avoidance. They tend not to take on tasks of special complexity, and in difficult situations, they are ready to refuse to perform complex projects that require special effort to complete. A special obstacle to the success of self-realization is a high level of situational barriers, which are, first, uncertainty in their abilities when faced with a difficult task, the opinion of others, underestimation of their personal, volitional and cognitive resources, lack of sufficient experience.

The second cluster with significant values is represented by inertia, external locus of control, conservatism, and dissatisfaction with the quality of life. The set of specified components is a continuation of the variables of the first factor. Apparently, pessimism and avoidance motivation in educational and research activities form passive, inert behavior in these students. They prefer to do only what is regulated by their duties, that is, what is provided for in the curriculum and program. They do not show initiative, avoid additional tasks and projects. Of course, all this limits the possibilities of their self-realization. In their activities, communication, and behavior, they use mostly formulaic, conservative ways and techniques of self-expression that do not always achieve the desired result. At the same time, external factors and surrounding people play a huge role. They constantly check their actions with other people's deeds, look for approval, support, and evaluation. Most likely, this is why they experience dissatisfaction with the quality of their life. Since they do not live a full life, they do not show their full potential in various areas of the educational space. Their behavior and activity are more often dependent on a negative psychoemotional background, instability of positive emotions, which is an obstacle to self-expression.

The third factor includes such statistically significant characteristics of self-realization as attitudes of adaptation, personal barriers and dissatisfaction with the quality of life. The identified variables also indicate the difficulties of students' self-realization in a multicultural educational space. They are not satisfied with their achievements now, they reflect a lot on this subject experiencing negative emotions and tend to mostly adapt to the surrounding reality.

The specificity of self-realization of students with a socially dependent type of self-relation also has certain specific aspects demonstrated in Table 4. 
Table 4

Factor structure of self-realization variables in students with a socially dependent type of selfattitude $(n=154)$

\begin{tabular}{lrrr}
\hline \multicolumn{1}{c}{ Variables of self-realization } & Factor 1 & Factor 2 & Factor 3 \\
\hline Transformation ideas & 0,117 & 0,203 & 0,167 \\
\hline Adaptation ideas & $\mathbf{0 , 6 6 4}$ & 0,125 & 0,221 \\
\hline Activity & 0,189 & 0,098 & 0,176 \\
\hline Inertia & $\mathbf{0 , 7 0 9}$ & 0,109 & 0,218 \\
\hline Optimism & 0,115 & 0,225 & $-0,225$ \\
\hline Pessimism & 0,133 & $\mathbf{0 , 7 0 4}$ & 0,193 \\
\hline Internal locus of control & 0,191 & 0,158 & $-0,174$ \\
\hline External locus of control & $\mathbf{0 , 7 2 8}$ & 0,242 & 0,201 \\
\hline Motives for achievement & 0,219 & 0,099 & $-0,114$ \\
\hline Motives for avoidance & 0,098 & $\mathbf{0 , 6 7 4}$ & 0,177 \\
\hline Creativity & 0,112 & 0,236 & 0,111 \\
\hline Conservatism & $\mathbf{0 , 6 5 5}$ & 0,159 & 0,221 \\
\hline Satisfaction with quality of life & 0,201 & 0,226 & $-0,636$ \\
\hline Dissatisfaction with the quality of life & 0,167 & $\mathbf{0 , 6 2 8}$ & 0,124 \\
\hline Effectiveness & 0,091 & 0,133 & 0,205 \\
\hline Situational barriers & $\mathbf{0 , 6 7 1}$ & 0,252 & 0,142 \\
\hline Personal barriers & $\mathbf{0 , 5 4 9}$ & 0,228 & 0,123 \\
\hline
\end{tabular}

In the factor structure of these respondents' self-realization, the main load falls on the first factor, which actually determines the features of these students' self-realization. The specified factor with significant values includes adaptation ideas, inertia, external locus of control, conservativeness, situational and personal barriers. The set of marked features characterizes these students' self-realization as follows. These students tend not to be active in the educational space. In class, they usually prefer to sit in the back rows and do not usually participate in the discussion of current issues. Reports and projects are prepared exclusively at the request of the teacher. When reporting homework, they do only what is necessary; independence and initiative are almost absent. In research activities, they manifest themselves very rarely, but they are willing to participate in creative activities. Apparently, this is because by taking part in creative student activities, they receive more positive public support while demonstrating their creativity in front of a large number of students and teachers.

In the educational society, their behavior is adaptive, they use all their knowledge and experience to adapt to the situation. They cannot be called reformers or activists, they are always satisfied with everything and it is difficult for them to change something. They are too dependent on other students, teachers, and situations they find themselves in. They usually use standard patterns, simple expressions in their activities, communication, and behavior. Even if they show some creativity, it happens extremely rarely. At the same time, they often face difficulties in learning and communicating, especially with students from other countries due to their uncertainty, anxiety, low self-esteem and closeness. Their inertia and stereotyped behavior and thinking are an obstacle to free expression, which actually significantly reduces their potential for self-realization.

The second factor with significant values included pessimism, avoidance motives, and dissatisfaction with the quality of life. The third factor is only one variable of self-realization: dissatisfaction with the quality of life. These components of self-realization support the significant variables of the first factor. In other words, passivity of behavior, stereotyped thinking and adaptation tactics generate uncertainty in the effectiveness of their activities, reduce the psycho-emotional mood, do not motivate students to achieve and succeed in the educational environment. All this leads to dissatisfaction with the quality of life, apathy, fatigue and frustration. Students do not go beyond the set program; they strive to conform to others. They are alien to creativity in the educational process; they prefer standard schemes for obtaining professional competencies. None of the above contributes to the full students' self-realization in a multicultural educational space. As a rule, these students are grouped into micro-teams based on national, ethnic and state characteristics. One can most often see such groups of Chinese, Vietnamese, Korean, Spanish and other groups of Latin American students. Of interest is the fact that their compatriots with other parameters of self-relation quite successfully realize themselves in the same educational environment. 


\section{Discussion}

In general, the results of the empirical study confirmed the assumption that the features of students' self-attitude can be predictors of self-realization in a multicultural educational space.

To identify the dependence of these characteristics, a correlation analysis was performed. The results of correlation dependence also revealed some specific aspects in different groups of students' self-attitude (2-4). Figure 2 shows correlations of variables of self-attitude and self-realization with a level of significance not lower than $p<0.05 \%$ in students with a positive-stable type of self-attitude.

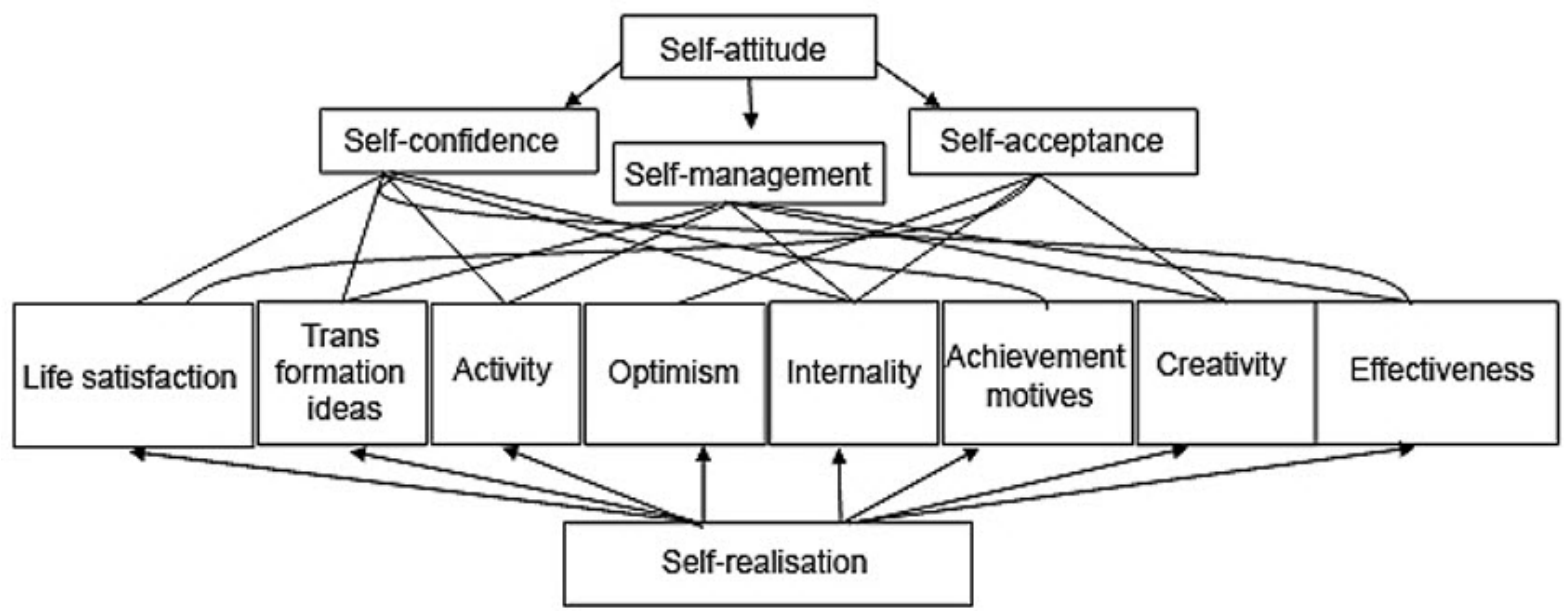

Figure 2. Correlations of components of self-attitude and self-realization in students with a positivestable type.

Students with this type of self-attitude have stable links among such characteristics of self-attitude as self-confidence, self-guidance and self-acceptance as well as most of self-realization variables. Thus, self-confidence at a statistically significant level correlates with such indicators of self-realization as conversion attitudes, activity, optimism, motivation for achievement, performance and satisfaction with the quality of life. Direct dependence indicates a mutual process, the more confidence is expressed in students on the scale, the more intensely they manifest transformation ideas focused on changing the surrounding reality, their cognitive and social activity is maximally realized, they are more confident and optimistic about the future, and positively evaluate the present. The combination of these characteristics provides respondents with a high performance of the self-expression process and satisfaction with the quality of life. Self-management is positively correlated with activity, the internalized locus of control, and creativity. The more self-directed students become, the more active, regulated, and creative their behavior is and, consequently, their self-expression in the educational space becomes. Self-acceptance is also statistically significantly related to internal self-regulation, performance, and life quality satisfaction.

The discovered galaxy of correlations proves a direct correlation between self-attitude and selfrealization. Students with a positive-stable type of self-attitude, self-realization in a multicultural educational space is carried out quite effectively.

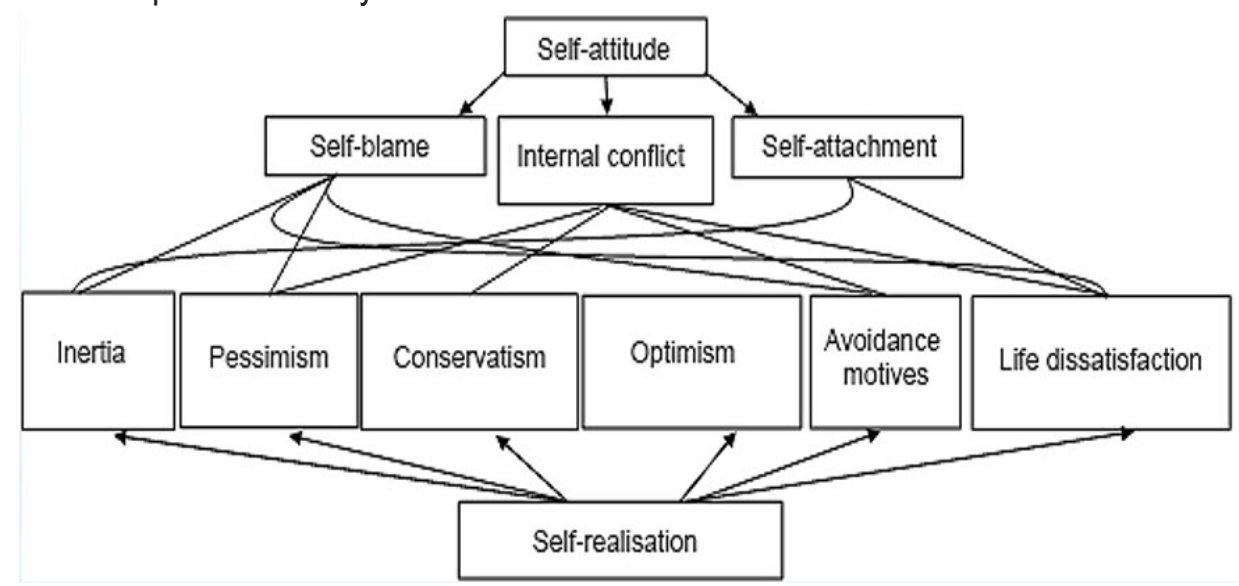

Figure 3. Correlations of components of self-attitude and self-realization in students with a negativerigid type. 
The analysis of interrelations of self-realization and self-attitude in students with this type shows a different architecture of component dependencies. Self-blame, internal conflict, and self-attachment are the main characteristics of self-attitude that are interrelated with the variables of self-realization. Self-blame is positively correlated at a statistically significant level with such self-actualization variables as inertia, pessimism, avoidance motives, and dissatisfaction with the quality of life. In other words, focusing on their shortcomings, failures in activities and communication, on their weak points reduces the cognitive and social activity of such students. These students are sedentary, they have a reduced range of interests, they experience negative emotional states, and they see everything in an unfavorable light. They rarely conclude any educational, scientific or creative projects at a high quality level. They always anticipate failure and difficulties at the very beginning of the task. For this reason, they always try to isolate themselves from difficult work, because there is a fear of showing themselves as a loser. They strive to avoid difficult situations and tasks, and expect low results. Hence, they are dissatisfied with the quality of life. They are not satisfied with the results of their activities; they are not able to express themselves as much as possible in various spheres of life because their rigidity and pessimism prevent them from it.

Internal conflict is positively correlated with pessimism, conservatism, avoidance motivation, and dissatisfaction with the quality of life. Specific attitude toward their own "self" manifested in finding the negative sides of the personality, expression of self-control and a negative self-assessment of one's person leads to a slowdown in activities, negative perception of reality, stereotyped ways and techniques of expression, and to avoid difficulties and dissatisfaction with their position in a student community. Finally, self-attachment is statistically significantly correlated with dissatisfaction with quality of life and inertia. In other words, the more rigid students are in relation to their traits, the more they feel their passivity, lack of desire to change something in themselves and their activities, in their environment. In the end, this leads to dissatisfaction with their position in the educational environment. There is no sense of joy from activity, self-expression and communication.

The correlation between the marked characteristics of self-attitude and self-realization in students with a negative-rigid type indicates, first, the interdependence of these phenomena, and secondly, shows the difficulties of self-realization due to low activity, rigidity of behavior and thinking, weak motivation, and a negative assessment of their "self". Figure 4.

The interdependence of self-realization variables and self-relationship components is shown in

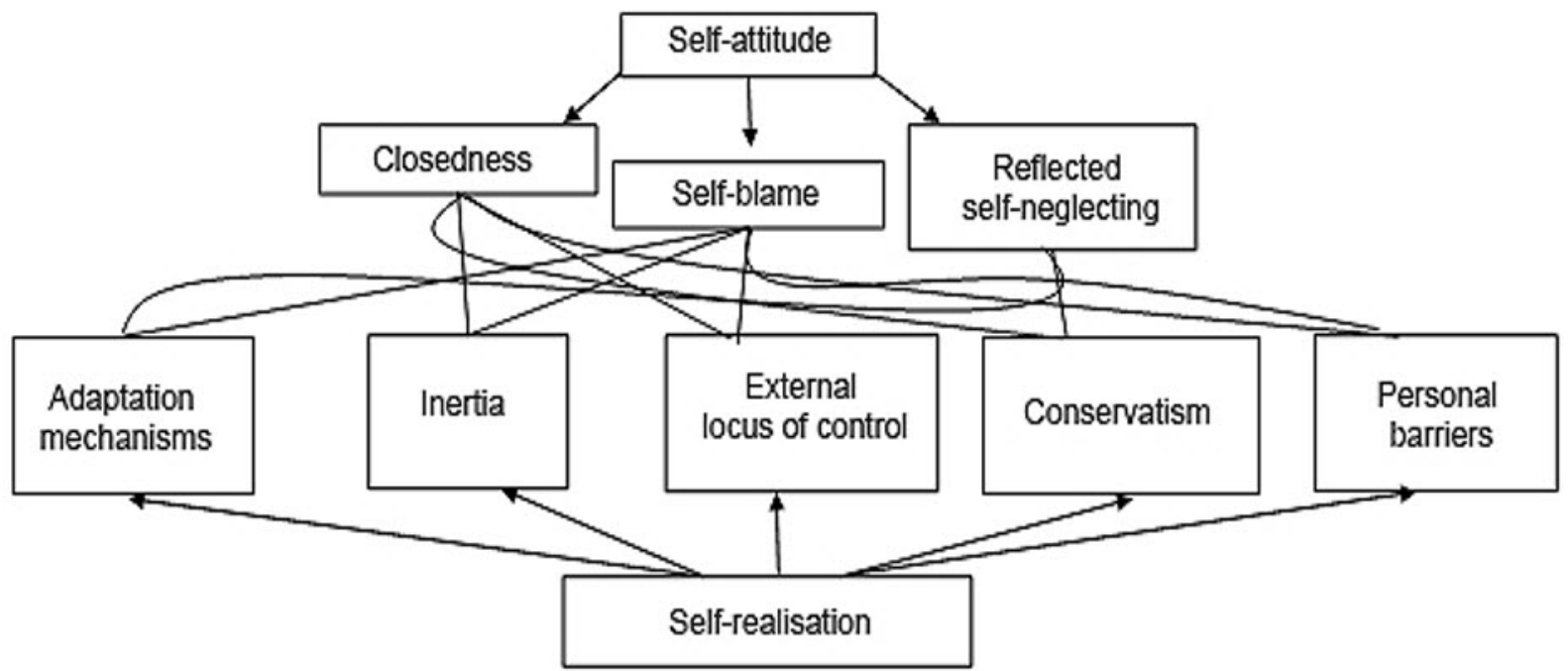

Figure 4. Correlations of components of self-attitude and self-realization in students with a socially dependent type of self-attitude.

As it can be seen in the figure, the students with a socially dependent type of self-attitude, the correlative pleiades include closeness, self-blame, and reflected self-attitude. These characteristics have the largest number of statistically significant correlations with self-actualization variables. Thus, closeness is positively correlated with inertia, external self-regulation, conservatism, and personal barriers. The expressed protective behavior of the person, due to a desire to conform to accepted norms, significantly reduces the manifestation of social and cognitive activity of students, enhances the influence of others on their behavior and self-expression, limits the expression of non-standard, creative ways and techniques of expression, but also contributes to the development of dependence on others, the development of 
insecurity, anxiety, which subsequently acts as a barrier to self-actualization. Self-blame is positively associated with adjustment attitudes, inertia, external self-regulation, and personal barriers. The more students focus on their shortcomings, the more clearly their behavior is aimed at ignoring difficulties in activity communication and behavior. This is confirmed by their inert behavior and their self-regulation dependence on the surrounding teachers and students, as well as a complex of personal barriers in the form of anxiety, uncertainty, laziness and disorganization. The reflected self-attitude, in turn, is correlated at a statistically significant level with the ideas of adaptation and conservatism. Students' awareness that they are valued by others for their personal and spiritual qualities, for their actions and deeds, as well as for their adherence to group norms and rules, strengthens their adaptive behavior mechanism and standard ways of self-expression in a multicultural educational space. At the same time, it acts as a barrier to self-realization because students do not go beyond the standard schemes of self-expression; do not show creativity and over-activity.

It should be noted that the correlation of self-relation with various personal and professional characteristics of students is also obtained in the study of other authors. For example, in Shutenko et al., 2020 and other works there was also a correlation between the level of self-motivation characteristics and features of self-attitude of students (Shutenko et al., 2020). Zh. G. Garanina's et al., work examines the role of self-attitude in personal and professional development of graduate students (Garanina, Balyaev and lonova, 2019). However, the typology of groups of students with different characteristics of selfattitude and, accordingly, different results of self-realization presented in this study is an original empirical work carried out in the educational environment of a modern international university.

\section{Conclusion}

The conducted theoretical research allowed us to determine that the multicultural educational environment, on the one hand, acts as a favorable factor for the individual's self-expression through interaction with students from other countries, which allows them to join a different culture, its traditions and values, and expand their cognitive space. On the other hand, the multicultural environment acts as a socio-psychological barrier to students' self-realization, due to communication difficulties and different mentalities of students from Europe, Asia and Africa.

The analysis of modern research on the problem of self-realization has shown that various psychodynamic, emotional-volitional and motivational-semantic characteristics of the subject of activity act as the subject determination of the individual's self-realization. The success of self-realization is largely determined by the totality, ratio, and degree of expression of these characteristics. For example, a pronounced perseverance does not yet allow students to realize their full potential, but if this property lets the subject of activity clearly express and direct motivation, positive self-attitude, realize the goal deeply, use creative non-standard schemes of self-expression, the effectiveness of self-realization significantly increases.

In the course of the empirical study, using methods of mathematical statistics, three different types of students' self-attitude with the conditional names positive-stable, negative-rigid and socially dependent were identified and characterized. The qualitative characteristics of the self-attitude of each of the selected types have been determined. It is established that there are differences in the specifics of students' self-realization in a multicultural educational space with different types of self-attitude. It is proved that students with a positive and stable type of self-attitude realize themselves most successfully in the process of educational activity in a multicultural educational environment, due to the expression of such characteristics as high self-esteem, self-confidence, self-control, self-worth and self-acceptance. At the same time, students with a socially dependent type of self-attitude experience the greatest difficulties in self-realization. The main barriers to self-fulfillment are closeness, self-blame, low self-esteem, rigidity, pessimism, social and cognitive passivity.

It is established that the identified types of self-relation have specific links with the components of self-realization. In a positive-stable type of self-attitude, these connections involve such characteristics of self-realization as transformation ideas, achievement motives, creativity, effectiveness, and optimism, which provides a success rate of the self-realization process. While in the socially dependent type of selfattitude, the main correlation pleiades cover inertia, pessimism, dependence of self-regulation on external circumstances, stereotypical self-expression, motives of avoidance, which certainly reduce the quality of self-realization of the students' personality.

The facts and specific patterns of students' self-realization in a multicultural educational space with different types of self-attitude revealed in the course of the study will allow us to take these data into 
account in the future when developing programs for psychological support of foreign students during their studies, especially during the adaptation period. In addition, the results obtained can be used to develop programs for foreign students' individual learning paths in a multicultural educational environment.

\section{Acknowledgments}

The article is made in the framework of the initiative of NIR No. 050423-0-000 "Internet-space as an Innovative Environment for Personal Self-realisation in Contemporary Society", performed on the basis of social and differential psychology department of Peoples' Friendship University of Russia (RUDN University).

\section{Conflict of interests}

The authors declare no conflict of interest.

\section{References}

Bandura, A. (1995). On rectifying conceptual ecumenism. In J. E. Maddux (Ed.), The Plenum series in social/clinical psychology. Self-efficacy, adaptation, and adjustment: Theory, research, and application. 347-375. Plenum Press. https://doi. org/10.1007/978-1-4419-6868-5 13

Berzonsky, M.D., \& Papini, D.R. (2014). Identity Processing Styles and Value Orientations: the mediational role of selfregulation and identity commitment. Identity. An international journal of theory and research, 14(2), $96-112$. https:// doi.org/10.1080/15283488.2013.858228

Bokhan, T. G., \& Peshkovskaya, A. G. (2011). Трудности самореализации в субъективной картине жизненного пути больных алкоголизмом. [Challenges of self-realization in subjective picture of life span of patients with alcoholism]. Siberian Gerald of Psychiatry and Addiction Psychiatry, 2(65), 34-40. https://elibrary.ru/item.asp?id=16209978

Denisova, E. A., \& Vorobyeva, N. A. (2017). Gender differences of self-attitude of today's adolescents. Science Vector of Togliatti State University. Series: Pedagogy, Psychology, 3(30), 48-53. https://doi.org/10.18323/2221-5662-2017-3-4853

Chzhan, T. (2013). Возрастные особенности профрессиональной самореализации личности (на примере специалистовмаркетологов из KHP). [Age Peculiarities of Professional Self-Realization of Personality (by the Example of the Experts in Marketing from the People's Republic of China)]. RUDN Journal of Psychology and Pedagogics, 3, 49-54. https:// elibrary.ru/item.asp?id=20290126

Chzhan, P. H., \& Chzhan, T. (2013). Половые различия самореализации личности Китайских студентов. [Gender Distinctions of Personality Self-Realization in Chinese Students]. RUDN Journal of Psychology and Pedagogics, 2, 20-25. https://elibrary.ru/item.asp?id=19091041

Egorycheva, I. D. (2019) Самореализация на ранних этапах онтогенеза (к постановке проблемы). [Self realization in the early stages of ontogenesis (to the formulation of the problem)]. Mir psihologii. 2(98), 207-217. https://elibrary.ru/item. asp?id=41311523

Galazhinskij, E.V. (2006). Психологические основания изучения полноты и качества процессов самореализации личности. [Investigating personal self-realization quality and completeness: the psychological bases]. Sibirskiy Psikhologicheskiy Zhurnal, 24. 70-76. https://elibrary.rulitem.asp?id=12512580

Garanina, Z. G., Balyaev, S. I., \& lonova, M. S. (2019). Роль самоотношения в личностно-профрессиональном саморазвитии студентов высшей школы. [The role of self-attitude in the personal and professional development of high school students]. The Education and science journal, 21(1), 82-96. https://doi.org/10.17853/1994-5639-2019-1-82-96

Grigorieva, A. A., \& Povarionkov, J. Р. (2015). Проблема соотношения и взаимодействия проффессиональной самоактуализации и профеессиональной самореализации личности. [Problem of the correlation and interaction of professional self-actualisation and professional self-realization of the personality]. Yaroslavl Pedagogical Bulletin, 3. 166-174. https://elibrary.ru/item.asp?id=24835457

Guichard, J. (2005). Life-long Self-Construction. International Journal for Educational and Vocational Guidance, 5, 111-124. http://doi.org/10.1007/s10775-005-8789-y

Hammad, S. М. (2013). Исследования самореализации личности в России и за рубежом. [Research of personality selfactualization in Russia and abroad]. RUDN Journal of Psychology and Pedagogics, (3), 44-48. https://elibrary.ru/item. asp?id=20290125

Hartung ,P.J., Porfeli, E.J., \& Vondracek ,F.W. (2005). Vocational development in childhood.A review and reconsideration. Journal of Vocational Behavior, 66(3), 385 - 419. http://doi.org/10.1016/j.jvb.2004.05.006

Korostyleva, L. A. (1997). Problemy samorealizacii lichnosti v sisteme nauk o cheloveke. [Problems of personality selfrealization in the system of human sciences]. Psihologicheskie problemy samorealizacii lichnosti. 354.

Kostakova, I.V., \& Belousova (Grigoreva) S. S. (2014). Психологическая основа профессиональной самореализации личности. [Psychological basis of career and job satisfaction in adults]. National Psychological Journal, 3(15), 80-85. http://doi.org/10.11621/npj.2014.0310

Kudinov, S. I., \& Kudinov, S. S. (2017). Razrabotka metodiki issledovaniya samorealizacii lichnosti [Development of a research methodology for personality self-realization]. Vysshaya shkola: opyt, problemy, perspektivy: materialy Mezhdunarodnoj nauchno-prakticheskoj konferencii, 3-15. https://elibrary.ru/item.asp?id=29886503

Kudinov, S. I., \& Kudinov, S. S. (2018). Psihodiagnostika lichnosti [Psychodiagnostics of personality]. Moscow: RUDN, https:// elibrary.ru/item. asp?id=34993454 
Kudinov, S. I., \& Aybazova, S. R. (2015). Субъектная детерминация самореализации личности. [Subject Determination of Self-realization of Personality]. Acmeology, 2(54), 90-97. https://elibrary.rulitem.asp?id=23485443

Kudinov, S. I., Avdeyev, N. P., \& Arkhipochkina, K. V. (2012). Индивидуально-типологическая характеристика самореализации личности. [The article presents the analysis of the empirical results of the study with the purpose to identify the different types of personal fulfillment]. RUDN Journal of Psychology and Pedagogics, 4, 85-90. https:// elibrary.ru/item.asp?id $=18258602$

Kudinov, S. I., Aybazova, S. R., \& Arkhipochkina, K. V. (2015). Темпераментальные предпосылки самореализации личности. [Temperamental Prerequisites of Personality Self-Realization]. RUDN Journal of Psychology and Pedagogics, 1, 1825. https://elibrary.ru/item.asp?id=23133822

Kudinov, S. I., Davydova, N. I., \& Kudinov, S. S. (2018). Specificity of self-realization of teachers with various length of professional experience. RUDN Journal of Psychology and Pedagogics, 15(3), 271-286. https://doi.org/10.22363/23131683-2018-15-3-271-286

Kudinov, S. I., Kudinov, S. S., Kudinova, I. B., \& Mikhailova, O. B. (2017). The role of persistence in students'self-realization. International Journal of Cognitive Research in Science, Engineering and Education, 5(2), 19-26. https://doi.org/10.5937/ IJCRSEE1702019K

Kudinov, S.I., Kudinov, S.S., Kudinova, I.B., Mihailova, O.B., Avagian, K.K. (2019). The differences in ethnic identity and patriotism characteristics between Russian and Kazakh students. Zbornik Instituta za Pedagoska Istrazivanja, 51(1), 285-325. https://doi.org/10.2298/ZIPI1901285K

Kudinov, S. S. (2013). Individually-Typological Peculiarities of Personality Self-Discipline and Self-Actualization Correlation. RUDN Journal Of Psychology And Pedagogics, (2), 14-19. http://journals.rudn.ru/psychology-pedagogics/\%20article/ view/7746

Kudinova, I. B., \& Belousuva, S. S. (2017). Relationship Between Spiritual and Moral Self-consciousness and Self-realization in Adulthood. RUDN Journal of Psychology and Pedagogics, 1(17), 38-51. https://doi.org/10.22363/2313-1683-201714-1-38-51

Kulagina, I.V. (2016). The Study of Psychological Adaptation and Creative Self-realization. Международный научноисслдовательский журнал, 11-5(53), 110-111. https://doi.org/10.18454/IRJ.2016.53.133

Leary, M. R., Nezlek, J. B., Downs, D., Radford-Davenport, J., Martin, J., \& McMullen, A. (1994). Self-presentation in everyday interactions: effects of target familiarity and gender composition. Journal of personality and social psychology, 67(4), 664-673. https://doi.org/10.1037/0022-3514.67.4.664

Leontiev, D., Lebedeva, A., \& Kostenko, V. (2017). Pathways of Personality Development: Following Lev Vygotsky's Guidelines. Educational Studies, 2, 98-112. Yaroslavl Pedagogical Bulletin. https://doi.org/10.17323/1814-9545-2017-2-98-112

Shutenko, E. N., Shutenko, A. I., \& Kanishcheva, M. A. (2020). Personal features of students'self-realization in the university educational environment. Азимут научных исследований: педагогика и психология, 9(1), 403-407. https://doi. org/10.26140/anip-2020-0901-0098

Solodnikova, I. (2018). Life strategies implementation by ex-participants of youth subcultures. Vestnik RGGU. Seriya:Psihologiya. Pedagogika. Obrazovanie, 2(12), 60-80. https://doi.org/10.28995/2073-6398-2018-2-60-80

Stošić, L., Dermendzhieva, \& S. Tomczyk, L. (2020). Information and communication technologies as a source of education. World Journal on Educational Technology: Current Issues,12(2), 128-135. https://doi.org/10.18844/wjet.v12i2.4815

Stošić, L., \& Fadiya, S. O. (2017). The attitudes of students towards the use of ICT during their studies. Российский психологический журнал, 14(1), 135-148. https://doi.org/10.21702/rpj.2017.1.9

Stošić, L., \& Stošić, I. (2015). Perceptions of teachers regarding the implementation of the internet in education. Computers in Human Behavior, 53(12),462-468. https://doi.org/10.1016/j.chb.2015.07.027

Vartanova, I. I. (2016). Sistema tsennostei, motivatsiya i samootnoshenie: gendernaya spetsifika starsheklassnikov [The system of values, motivation and self-attitude: the gender specificity of high school students]. Natsional'nyi psikhologicheskii zhurnal [National Psychological Journal], 4(24). 115-121. https://doi.org/10.11621/npj.2016.0414

Vianello, M., Schnabel, K., Sriram, N., \& Nosek, B. (2013). Gender differences in implicit and explicit personality traits. Personality and individual differences, 55(8), 994-999. https://doi.org/10.1016/j.paid.2013.08.008

Waterman, A. S., Schwartz, S. J., Goldbacher, E., Green, H., Miller, C., \& Philip, S. (2003). Predicting the subjective experience of intrinsic motivation: The roles of self-determination, the balance of challenges and skills, and self-realization values. Personality and Social Psychology Bulletin, 29(11), 1447-1458. https://doi.org/10.1177/0146167203256907

Yudakina, S. (2013) Концепция поликультурной образовательной среды формирования толерантности. [Concept of multicultural educational milieu of tolerance formation]. Innovation in science, 19, 213-219. https://www.elibrary.ru/item. asp?id=20520612 
Kudinov, I. S. et al. (2020). Different self-attitude indicators in students and their self-realization in a University, International Journal of Cognitive Research in Science, Engineering and Education (IJCRSEE), 8(3), 47-59. 